\title{
Seasonal abundance in Skagerrak-Kattegat coastal waters and host specificity of viruses infecting the marine photosynthetic flagellate Micromonas pusilla
}

\author{
Elisabeth Sahlsten* \\ General and Marine Microbiology, Department of Cellular and Molecular Biology, Göteborg University, Box 462, \\ S-405 30 Göteborg, Sweden
}

\begin{abstract}
Seawater sampled in the Skagerrak and Kattegat coastal waters during the period October 1995 to September 1996 were screened for the occurrence of viruses lytic to marine microalgae. Viruses lytic to the photosynthetic marine picoflagellate Micromonas pusilla (Butcher) Manton \& Parke (Prasinophyceae) were detected in all seawater samples screened. Evidence for viral lysis of any other of the 11 algal species tested was not obtained. Several viruses infecting different strains of $M$. pusilla were isolated. Ten isolated viruses which were tested for host specificity were found to be species specific to $M$. pusilla and even strain specific to $1-3$ of the 6 strains of $M$. pusilla used in the experiment. In the Skagerrak and Kattegat the seasonal abundance of viruses infectious to a $M$. pusilla strain isolated from the Oslofjord, Norway, was at least 1 order of magnitude higher (average $2.5 \times 10^{5} \mathrm{I}^{-1}$ ) than viruses infecting $2 \mathrm{M}$. pusilla strains isolated from Gulf of Maine, USA (average $2.2 \times 10^{4}$ and $4.6 \times 10^{3} \mathrm{I}^{-1}$, respectively)
\end{abstract}

KEY WORDS: Virus - Microalga Prasinophyceae $\cdot$ Strain specificity $\cdot$ Skagerrak $\cdot$ Kattegat

\section{INTRODUCTION}

Viral particles are found in high abundance in natural waters and they appear to be an active component of the marine ecosystem. Viruses infecting bacteria, bacteriophages, are the most thoroughly studied of the marine viruses (e.g. Borsheim 1993, Bratbak et al. 1994, Suttle 1994). The impact and abundance of viruses which infect marine microalgae were not recognised until recent years. Indications of virus infection in microalgae have been obtained with transmission electron microscopy (TEM) preparations of planktonic material collected from seawater (Proctor \& Fuhrman 1991, Nagasaki et al. 1994). The electron micrographs showed heavily stained virus-like particles (VLPs) inside the cells of several groups of marine microalgae and bacteria. Algal viruses may be impor-

·E-mail: sahlsten@gmm.gu.se tant factors in algal communities, regulating nutrient cycling and influencing algal species succession in the pelagic system (e.g. Fuhrman \& Suttle 1993). Experimental studies, increasing the number of viruses in seawater samples by adding natural viral concentrates in the size range 2 to $200 \mathrm{~nm}$, have strengthened the conclusions that marine viruses may have an impact on the phytoplankton population and may inhibit their photosynthesis (Suttle et al. 1990, Suttle 1992).

Despite the fact that 2 species-specific viruses have been detected in samples containing the 2 bloomforming haptophytes Phaeocystis pouchetii (Jacobsen et al. 1996) and Emiliania huxleyi (Bratbak et al. 1996) in Norwegian coastal waters, still not much is known about the impact of marine viruses on algal blooms.

Availability of experimental host-virus systems is the key to learning more about the ecological significance of algal viruses. Viruses have been found in algal cells from all major taxonomic classes but only a few have been brought into culture. Viruses infective to the pra- 
sinophyte Micromonas pusilla (Butcher) Manton \& Parke (Mayer \& Taylor 1979, Cottrell \& Suttle 1991) $(\mathrm{MpV})$ were some of the first marine viruses isolated, but still not much information has been collected on factors regulating the infection and replication process of the virus in the alga.

Species specificity of algal viruses may be a mechanism to maintain diversity in phytoplankton communities (Cottrell \& Suttle 1991). The host range and specificity to different host strains may vary between different viral strains as has been found for Synechococcus phages (Suttle \& Chan 1993, Waterbury \& Valois 1993). Waterbury \& Valois (1993) concluded that the acquisition and maintenance of resistance by Synechococcus spp. to their co-occurring phages permit these cyanobacteria to coexist stably with a diverse group of cyanophages that can be present at high titers in seawater.

The aim of the present study was to initiate investigations in Swedish coastal waters on the occurrence and dynamics of viruses that infect marine microalgae. The questions asked were: What species of microalgae are infected? To what degree are the viruses hostspecific? Are there any seasonal dynamics? The aim was also to obtain viral isolates suitable for experimental studies in the laboratory on the host-virus system of a marine microalga and its specific lytic virus.

\section{MATERIALS AND METHODS}

Concentrating viruses from seawater. Large volumes (20 to 60 l) of surface seawater were collected from the Kattegat and Skagerrak North Atlantic coastal waters by $30 \mathrm{l}$ Niskin bottles and kept dark at $4{ }^{\circ} \mathrm{C}$ in polyethylene carboys. The water was prescreened by pressure filtration through two $142 \mathrm{~mm}$ diameter filters (a GF/C glass fibre filter [Whatman] followed by a $0.45 \mu \mathrm{m}$ pore size Durapore filter [Millipore]). The filtrate was concentrated approximately 100 - to 300 -fold by ultrafiltration with a $30000 \mathrm{MW}$ cut-off ultrafilter (Amicon Spiral Cartridge Model S1Y30) according to Suttle et al. (1991).

Algal cultures. Unialgal cultures of 12 marine microalgae, representing species common in the KattegatSkagerrak area and belonging to the taxonomic groups Prasinophyceae, Bacillariophyceae, Dinophyceae, Prymnesiophyceae, Cryptophyceae, and Chlorophyceae, were grown. in artificial seawater (Harrison et al. 1980) enriched with f/2 nutrients (Guillard \& Ryther 1962, Guillard 1975) in the laboratory using artificial light ('daylight fluorescent tubes', $80 \mu \mathrm{E} \mathrm{s} \mathrm{s}^{-1} \mathrm{~m}^{-2}$ ) with a 12:12 h light:dark cycle. The growth medium for the 6 strains of the flagellate Micromonas pusilla (Prasinophyceae) was supplemented with $5 \mathrm{mM}$ tris- $\mathrm{HCl}(\mathrm{pH}=$
7.7) and $10 \mathrm{nM} \mathrm{Na} \mathrm{SeO}_{3}$ according to Cottrell \& Suttle (1991).

Screening tests for viral infection and lysis of algae. The algae were grown in $10 \mathrm{ml}$ polypropylene screwcapped glass tubes. The growth of the cultures was monitored by measuring the in vivo chlorophyll a fluorescence with a Turner Model 111 fluorometer equipped with a blue (Corning 560) primary filter and a red (Coming 2-64) secondary filter. The culture tubes fitted the cuvette holder of the fluorometer and measurements could thus be made directly without subsampling or removing the culture from the tubes. When the algal cultures reached exponential growth phase, an inoculate of $1 \mathrm{ml}$ seawater concentrate was added to 5 parallel tubes, keeping 5 additional tubes as control. Virus infection indicated by lysis of the algae was seen as a drastic drop in fluorescence to near zero, while the fluorescence of the control cultures continued to stay high

Abundance of infectious viruses in seawater. The number of infectious viruses in the seawater concentrates were tested on the 3 Micromonas pusilla strains CCMP490, CCMP494, and LAC38 (Table 1). An inoculum of $60 \mu \mathrm{l}$ seawater concentrate was added to microtitre plates and mixed with $250 \mu$ l exponentially growing algal culture in 10-fold dilutions (Suttle 1993). The microtitre plates were inoculated in 10 parallel wells for each series of 10 -fold dilutions up to $10^{4}$-fold dilution. The microtitre plates were incubated at $20^{\circ} \mathrm{C}$ under approximately $5 \mu \mathrm{E} \mathrm{s}^{-1} \mathrm{~m}^{-2}$ fluorescent light for about $4 \mathrm{wk}$ and lysis was monitored every second day by measuring the in vivo chlorophyll a fluorescence (Cytofluor ${ }^{\mathrm{TM}} 2300$ Fluorescent Measurement System, Millipore, excitation filter 460/40, emission filter 660/40). The number of infective particles, i.e. lytic viral particles, per $\mathrm{ml}$ was calculated by the MPN method using a BASIC program (Hurley \&

Table 1. Micromonas pusilla strains used in the present study

Micromonas
pusilla strain

$\mathrm{CCMP}^{\mathrm{d}} 490$ Woods Hole, MA, USA (seawater tank debris)

CCMP485 Boothbay Hbr, Gulf of Maine, USA

CCMP494 Gulf of Maine, USA

CCMP1545 The English Channel

CCMP491 The English Channel (reclone of CCMP 1545) LAC $^{\text {bे }} 38$ Oslofjord, Norway

${ }^{a} M$. pusilla strains named CCMP- were obtained from the Center for Culture of Marine Phytoplankton (CCMP) at Bigelow Laboratory for Oceanic Sciences

${ }^{b}$ Algal strain called LAC- was obtained from the Culture Collection of The Marine Research Center of Göteborg University 
Roscoe 1983). An estimate of in situ abundance was made by assuming approximate 100 -fold and 300 -fold concentration factors from 20 and $60 \mathrm{l}$ of seawater, respectively.

Virus isolation. Viruses were isolated from the Skagerrak and Kattegat by repeatedly transferring an inoculum from a lysed batch culture of Micromonas pusilla to an exponentially growing culture of the same strain at least 5 times. The resulting lysate was stored at $4^{\circ} \mathrm{C}$ and used as the stock virus sample. Observations by TEM of viruses collected on electron microscope grids and negatively stained (Bratbak et al. 1990) showed the virus particles (of the viral isolate MpVUF8-490) to be morphologically homogenous and hexagonally shaped. The nature of infection of 8 of the $\mathrm{MpV}$ isolates which were used in the present study was investigated, either by filtering through sterile $0.1 \mu \mathrm{m}$ pore size membrane filter (Millex-VV, Millipore), or autoclaving $\left(120^{\circ} \mathrm{C}, 20 \mathrm{~min}\right)$, before inoculating to $M$. pusilla host cultures in 10 replicate wells of microtitre plates and incubated as above. To examine bacterial growth inoculates of $100 \mu$ l were spread onto agar plates composed of algal medium enriched with organic substrates (per $1000 \mathrm{ml}$ algal medium $1.0 \mathrm{~g}$ peptone, $0.5 \mathrm{~g}$ yeast extract, $0.5 \mathrm{~g}$ glucose, $0.5 \mathrm{~g}$ soluble starch, $0.01 \mathrm{~g} \mathrm{FeSO}_{4} \cdot 7 \mathrm{H}_{2} \mathrm{O}$, and $0.01 \mathrm{~g} \mathrm{Na}_{2} \mathrm{HPO}_{4}$ were added) and $1.5 \%$ agar.

Host specificity. 'The host specificity for lytic infection was studied for $8 \mathrm{MpV}$ isolates, originating from the Kattegat and Skagerrak. Species specificity was examined for the 12 microalgal species Micromonas pusilla, Tetraselmis sp., Skeletonema costatum, Ditylum brightwellii, Thalassiosira weissflogii, Chaeto-

Table 2. Strain specificity of Micromonas pusilla viral isolates from the Kattegat and Skagerrak, investigated with inoculates of viral isolates filtered through $0.2 \mu \mathrm{m}$ filters. The first number in the name of the viral isolate refers to the seawater sample from which the virus was isolated and the last number refers to the $M$. pusilla host strain, in which the virus was first amplified. + : lysis, i.e. fluorescence decreased to less than $5 \%$ of control; $(+)$ : no clear lysis, i.e. fluorescence decreased to $5-50 \%$ of control; - : no lysis, i.e. no decrease/ fluorescence higher than $50 \%$ of control

\begin{tabular}{|lcccccc|}
\hline \multirow{2}{*}{ Viral isolate } & \multicolumn{7}{c|}{ Micromonas pusilla strain } \\
& LAC & CCMP & CCMP & CCMP & CCMP & CCMP \\
& 38 & 1545 & 490 & 485 & 494 & 491 \\
\hline MpVUF8-490 & - & + & + & - & - & + \\
MpVUF8-1545 & - & + & + & - & - & + \\
MpVUF9-38 & + & - & - & + & - & - \\
MpVUF10-38 & + & - & - & + & - & - \\
MpVUF11-38 & + & ++ & - & + & - & - \\
MpVUF12-38 & + & - & - & ++ & - & - \\
MpVUF15-490 & - & + & + & ++ & - & + \\
MpVUF16-490 & - & - & + & + & - & - \\
\hline
\end{tabular}

ceros sp., Phaeodactylum tricornutum, Prorocentrum minimum, Chrysochromulina polylepis, Prymnesium parvum, Rhodomonas sp. and Dunaliella tertiolecta. Strain specificity was tested for 6 strains of $M$. pusilla (Table 1). In each experiment $50 \mu$ l of $0.2 \mu \mathrm{m}$ filtered lysate from a $\mathrm{MpV}$ infected and lysed host culture of $M$. pusilla was inoculated to $300 \mu$ algal culture in 10 parallel microwells, keeping 10 parallel controls. The microtitre plates were incubated and growth and lysis of the algal cells were monitored as above.

\section{RESULTS}

All of the seawater concentrates tested resulted in lysis of at least 1 strain of the prasinophycean flagellate Micromonas pusilla, but no other microalgal species were lysed.

Eight Micromonas pusilla-virus strains were isolated and found to be species specific to $M$. pusilla as no other algal species tested were visibly infected and lysed. In addition to the species specificity there was a pronounced strain specificity for lytic infection of 1 to 3 strains of the $6 \mathrm{M}$. pusilla strains tested (Table 2).

\section{Seasonal dynamics in occurrence of $\mathrm{MpV}$}

The highest numbers of lytic agents against Micromonas pusilla were found during spring (Fig. 1a), although no significant seasonal dynamics could be drawn from the present data. In all samples examined there was a clear dominance of viruses infecting the $M$. pusilla strain LAC38, on average $2.5 \times 10^{5}$ viruses $\mathrm{l}^{-1}$ (range $3.1 \times 10^{3}$ to $1.0 \times 10^{6} \mathrm{l}^{-1}$ ), with the highest abundance found in a surface water sample from the central Kattegat (station Fladen) in May 1996. Average abundance estimates of viruses infectious to $M$. pusilla strains CCMP494 and CCMP490 were respectively $2.2 \times 10^{4} \mathrm{1}^{-1}$ (range $8.2 \times 10^{1}$ to $5.6 \times 10^{4} \mathrm{l}^{-1}$ ) and $4.6 \times 10^{3} \mathrm{l}^{-1}$ (range $1.1 \times 10^{2}$ to $1.6 \times 10^{4} \mathrm{l}^{-1}$ ), i.e. 1 to 2 orders of magnitude less abundant than those infectious to strain LAC38.

\section{$\mathrm{MpV}$ isolates}

All of the $0.1 \mu \mathrm{m}$ filtered lysates were infective and the respective Micromonas pusilla host strain cultures were generally lysed within a week after the inoculation. Bacterial growth on agar was not detected in any of the $0.1 \mu \mathrm{m}$ filtrates. The results indicate that the infecting 


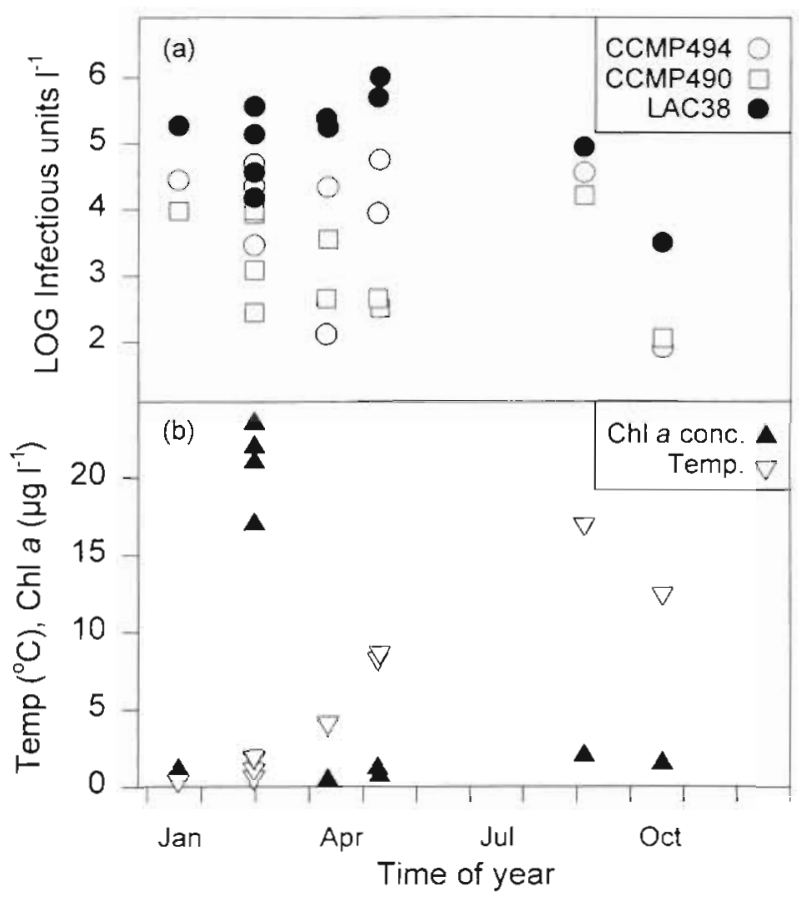

Fig. 1. Surface seawater samples from the Skagerrak and Kattegat. (a) Estimated number of infective lytic viruses, lysing the 3 different Micromonas pusilla strains CCMP494, CCMP490, and LAC38. (b) Ambient chlorophyll a concentration $\left(\mu \mathrm{g} \mathrm{l}^{-1}\right)$ and temperature $\left({ }^{\circ} \mathrm{C}\right)$

agents were not bacteria, but rather viruses small enough to pass the filter. The infectivity of the viruses was found to be destroyed by autoclaving as the autoclaved lysates did not lyse the algal cells. Preliminary studies of the negatively stained viruses (strain MpVUF8-490) in TEM showed homogenous hexagonal viruses of a size roughly estimated as 100 to $140 \mathrm{~nm}$, which indicates that these viruses may be similar to other isolates of Micromonas-infecting viruses (Cottrell \& Suttle 1991).

\section{DISCUSSION}

\section{Viral nature of lytic agent}

The filtration test of $\mathrm{MpV}$ isolates indicated that the lytic agents were viral particles. In the host-specificity test, the algal cultures were inoculated with viral lysates filtered through $0.2 \mu \mathrm{m}$ membrane filters. It is known (e.g Stockner et al. 1990) that $0.2 \mu \mathrm{m}$ membrane filters contain some holes that are larger than the manufacturers' stated nominal pore size. This means that some bacteria may have passed through the filter and it cannot be excluded that the inoculate may have contained some bacteria in addition to the viral particles. However, as all the original Micromonas pusilla host strains were lysed by $0.1 \mu \mathrm{m}$ filtered inoculates, it is most likely that lysis of the algae in all of the experiments were due to viruses specific to $M$. pusilla (MpV).

\section{Species and strain specificity of $\mathrm{MpV}$}

It is worth noting that the only alga which was clearly lysed by an inoculate of the seawater concentrates in this study was the picoflagellate Micromonas pusilla, and none of the other 11 algal species tested was clearly lysed. All the seawater samples which were screened for viruses were shown to contain agents lytic to $M$. pusilla. This sensitivity to virus infection found in $M$. pusilla, alternatively dominance of $\mathrm{MpV}$ among algal viruses, had already been noted by Mayer \& Taylor (1979) when testing their isolated viral particles on 46 planktonic algal isolates representing 35 species from 5 classes, which resulted in $M$. pusilla being the only alga lysed. However, Suttle et al. (1990) were successful in isolating several other lytic pathogens of phytoplankton of diverse taxonomy. One possible reason for the success in finding viruses lytic to M. pusilla may be that this prasinophyte is ubiquitous in almost all marine waters with a very good adaptability to changing temperature and salinity (Throndsen 1976. Throndsen \& Kristiansen 1991), and we have found it to be relatively easily kept in culture at the laboratory.

This is the first time that strain specificity has been reported in $\mathrm{MpV}$. The data (Table 2) indicate some relationships between e.g. strains CCMP1545, CCMP490 and CCMP491 and between LAC38 and CCMP485, as several isolated viruses are lytic to the members in either of these 2 groups. The total agreement between CCMP1545 and CCMP491 strengthens the indications of strain specificity as these 2 cultures originate from the same strain, isolated in the English Channel. CCMP491 is a reclone made by C. Suttle 1992, from this strain. Although 5 of the 6 Micromonas pusilla strains used in these experiments (Table 1) were isolated far away from the Kattegat and Skagerrak, all of the strains were lysed by at least some of the viruses in our samples. At this moment we do not have any information about the genetic differences between the isolated viruses or between the algal strains used in the experiments. Some of the isolated viruses may be identical, e.g. the 2 viruses, MpVUF8-490 and MpVUF8-1545, which were shown to have the same strain specificity and isolated from the same surface seawater sample at station Fladen, Kattegat in October 1995 on the $2 \mathrm{M}$. pusilla strains CCMP490 and CCMP1545, respectively (Table 2). It is thus possible 
that these could either be genetically identical or 2 separate viruses having the same host specificity. The specificity of viruses to different strains of $M$. pusilla has important ecological implications and is crucial when designing screening tests for viruses present in natural systems. The discrepancy in infectivity of viruses to the 3 tested strains of $M$. pusilla (Fig. 1a) indicated that a relatively local $M$. pusilla strain (LAC38 from the Oslofjord, Norway), was more suitable as a host to viruses collected in the KattegatSkagerrak area than algal strains isolated from the east coast of the Atlantic Ocean (CCMP494 and CCMP490 from coastal waters off Maine, USA). The abundance of $\mathrm{MpV}$ infective to $M$. pusilla strain LAC38 in spring 1996 in the Skagerrak and Kattegat (Fig. 1a) was in the same size range as the estimate of maximum abundance of $M$. pusilla algal cells $(1 \times$ $10^{6}$ cells $\mathrm{l}^{-1}$ ) at a Skagerrak coastal station in May 1993 (Karlson et al. 1996). Suttle \& Chan (1994) even found the concentration of viruses to exceed that of their host cells, the cyanobacteria Synechococcus, by as much as 6 to 8 times. There may be an ecological parallel between $\mathrm{MpV}$ and cyanophages, as cyanophages also have variable host ranges and have been found in highest concentrations when the host abundance was greatest (Suttle \& Chan 1994).

Unfortunately the abundance of Micromonas pusilla algal cells was not quantified in the present samples. Other studies in Skagerrak coastal waters (Kuylenstierna \& Karlson 1994, Karlson et al. 1996), however, have shown $M$. pusilla to be most abundant in spring, i.e. at the same time as the highest numbers of infectious viruses $\left(10^{5}\right.$ to $\left.10^{6} \mathrm{I}^{-1}\right)$ was detected in this study (Fig. 1a,b). There was no correlation between total chlorophyll a concentration and abundance of lytic $\mathrm{MpV}$ (infectious units) which can be explained by the fact that the picoplankton $M$. pusilla only accounts for a smaller portion of the total phytoplankton biomass, and the high chlorophyll a concentrations in March (Fig. 1b) were due to a spring bloom dominated by diatoms.

\section{Isolates of lytic algal viruses}

The method used in this work for isolating algal viruses is only selective for any lytic virus which infects an alga that is kept in culture in the laboratory. This paper is focussed on lytic viruses, and any existence of latent infection has not been investigated. However, it cannot be excluded that the negative results in detecting lytic infection in the algal species other than Micromonas pusilla could have been because these algae may already have been latent infected by viruses, which may have made the algae immune to further viral infection. Latent infection in microalgae has not yet been clearly proven, however.

Acknowledgements. The offshore seawater samples were helpfully taken by personnel at the SMHI Oceanographical Laboratory aboard RV 'Argos' The skilful technical assistance by A. $K$. Thell, F. Ziegler and A. Demelash is gratefully acknowledged. I thank $M$. Heldal at the Department of Microbiology, University of Bergen for help with the TEM technique, and F. Sörensson, 3 anonymous reviewers, and the subject editor for comments on the manuscript. This work was supported by funding from the Swedish Environmental Protection Agency, Axel och Margaret Ax:son Johnsons Stiftelse and Magn. Bergvalls Stiftelse.

\section{LITERATURE CITED}

Borsheim KY (1993) Native marine bacteriophages. FEMS Microbiol Ecol 102:141-159

Bratbak G, Heldal M, Norland S, Thingstad TF (1990) Viruses as partners in spring bloom microbial trophodynamics. Appl Environ Microbiol 56:1400-1405

Bratbak G, Thingstad F, Heldal M (1994) Viruses and the microbial loop: biotic factors. Microb Ecol 28:209-221

Bratbak G, Wilson W. Heldal M (1996) Viral control of Emiliania huxleyj blooms? J Mar Syst 9:75-81

Cottrell MT, Suttle CA (1991) Wide-spread occurrence and clonal variation in viruses which cause lysis of a cosmopolitan, eukaryotic marine phytoplankter, $M$ pusilla. Mar Ecol Prog Ser 78:1-9

Fuhrman JA, Suttle CA (1993) Viruses in marine planktonic systems. Oceanography 6:51-63

Guillard RRL (1975) Culture of phytoplankton for feeding marine invertebrates. In: Smith WL, Chanley MH (eds) Culture of marine invertebrate animals. Plenum Press, New York, p 29-60

Guillard RRL, Ryther JH (1962) Studies of marine planktonic diatoms. I. Cyclotella nana Hustedt and Detonula confervaceae (Cleve) Gran. Can J Microbiol 8:229-239

Harrison PJ, Waters RE, Taylor FJR (1980) A broad spectrum artificial seawater medium for coastal and open ocean phytoplankton. J Phycol 16:28-35

Hurley MA, Roscoe ME (1983) Automated statistical analysis of microbial enumeration by dilution series. J Appl Bact 55: $159-163$

Jacobsen A, Bratbak G, Heldal M (1996) Isolation and characterization of a virus infecting Phaeocystis pouchetii (Haptophyceae). J Phycol 32:923-927

Karlson B, Edler L. Graneli W, Sahlsten E, Kuylenstierna M (1996) Subsurface chlorophyll maxima in the Skagerrakprocesses and plankton community structure. J Sea Res 35:139-158

Kuylenstierna Mi Karlson B (1994) Seasonality and composition of pico- and nanoplanktonic cyanobacteria and protists in the Skagerrak. Botanica Mar 37:17-33

Mayer JA, Taylor FJR (1979) A virus which lyses the marine nanoflagellate $M$. pusilla. Nature 281:299-301

Nagasaki K, Ando M, Imai I, Itakura S, Ishida Y (1994) Viruslike particles in Heterosigma akashiwo (Raphidophyceae): a possible red tide disintegration mechanism. Mar Biol 119:307-312

Proctor LM, Fuhrman JA (1991) Roles of viral infection in organic particle flux. Mar Ecol Prog Ser 69:133-142

Stockner JG, Klut ME, Cochlan WP (1990) Leaky filters: a warning to aquatic ecologists. Can J Fish Aquat Sci 47:16-23 
Suttle CA (1992) Inhibition of photosynthesis in phytoplankton by the submicron size fraction concentrated from seawater. Mar Ecol Prog Ser 87:105 112

Suttle CA (1993) Enumeration and isolation of viruses. In: Kemp PF, Sherr BF, Sherr EB, Cole JJ (eds) Handbook of methods in aquatic microbial ecology. Lewis Publishers, Boca Raton, p 121-134

Suttle CA (1994) The significance of viruses to mortality in aquatic microbial communities. Microb Ecol 28:237-243

Suttle CA, Chan AM (1993) Marine cyanophages infecting oceanic and coastal strains of Synechococcus: abundance, morphology, cross-infectivity and growth characteristics. Mar Ecol Prog Ser 92:99--109

Suttle CA, Chan AM (1994) Dynamics of cyanophages and their effect on marine Synechococcus spp. Appl Environ Microbiol 60:3167-3174

Editorial responsibility: Gunnar Bratbak,

Bergen, Norway
Suttle CA, Chan AM, Cottrell MT (1990) Infection of phytoplankton by viruses and reduction of primary productivity. Nature 347:467-469

Suttle CA, Chan AM, Cottrell MZ (1991) Use of ultrafiltration to isolate viruses from seawater which are pathogens of marine phytoplankton. Appl Environ Microbiol 57: $721-726$

Throndsen J (1976) Occurrence and productivity of small marine flagellates. Norw J Bot 23:269-293

Throndsen J, Kristiansen S (1991) M. pusilla (Prasinophyceae) as part of pico- and nanoplankton communities of the Barents Sea. Polar Res 13:197-216

Waterbury JB, Valois FW (1993) Resistance to co-occurring phages enables marine Synechococcus communities to coexist with cyanophages abundant in seawater. Appl Environ Microbiol 59:3393-3399

Submitted: March 18, 1997; Accepted: May 25, 1998

Proofs received from author(s): October 26, 1998 